bers of the Society a greater return for their support, the Council authorized the officers to purchase books on business history and distribute them to members. It is hoped that at least one volume can be given free to the Society's members each year.

The Council also authorized the officers to negotiate for the reestablishment of the Journal of Economic and Business History. This quarterly publication, which was distributed to members of the Society from I 929 to 1932 , established an excellent reputation for scholarly work in business history. Since it was the only periodical in existence devoted to that subject, its suspension in 1932 constituted a real loss both to business men and students of history. It is hoped that the financial support necessary for its revival can be obtained in the near future.

\title{
Jere A. Downs
}

THE Society sustained a great loss in the death of Jere Arthur Downs on December 30, 1935, at his home, I Arlington Street, Winchester, Massachusetts. At the time of his death Mr. Downs was head of the Boston branch of Hayden, Stone \& Company, private bankers, and he had long been one of the outstanding figures in New England shipping business and financial life.

Born in Roxbury, August 21, 1872, Mr. Downs entered the employ of Hayden, Stone \& Company as a bookkeeper, shortly after the firm's establishment in 1892. In 1906 he was admitted to partnership, and he not only was an important factor in the subsequent growth of that house, but he soon became active in the control of many other business enterprises. Just before his death he was vice-president and director of the following concerns: Boston \& Yarmouth Steamship Company, Chinese American Investment Corporation, Nova Scotia Steamship Company, Old Dominion Steamship Company, Robert E. Lee Steamship Company. He was also a director of the American Pneumatic Service Company, Eastern Steamship Lines, Inc., Haystone Securities Corporation, Pond Creek Pocahontas Company, The Lamson Company, the Winchester Trust Company, The Wisconsin Zinc Company, and the Champion International Company. He had formerly served as president of the Boston Stock Exchange and as chairman of the board and of the executive committee of Eastern Steamship Lines, Inc.

Mr. Downs had been in poor health for two years and had been 
confined to his home for several months prior to his death. He had never married and is survived by his sister, Miss Elizabeth Downs. He had been a valued member of the Business Historical Society since 1927 and his passing constitutes a personal loss for many members and friends of the Society.

\section{Daniel G. Wing}

Just as the Bulletin was going to the printer, the Society received the sad news of the death of Daniel Gould Wing at his home in Brookline, Massachusetts, on January 27, 1936. Long a respected and admired leader in New England banking, Mr. Wing had, in September, 1935, resigned his position as chairman of the board of directors of the First National Bank of Boston on account of the ill health which had troubled him for many months.

Mr. Wing was born in Davenport, Iowa, September 10, I 868, and began his banking career in 1885 as a messenger for the State National Bank, Lincoln, Nebraska. Working up rapidly, he soon became cashier of the American Exchange National Bank of Lincoln, which he left in 1897 to become a national bank examiner. In this capacity he came to Boston in 1899 and was made receiver of the Globe National Bank and Broadway National Bank. Within only a few months he had shown such marked capacity that he was made a vice-president and director of the Massachusetts National Bank. Its president, John W. Weeks, was anxious to devote full attention to his own firm of Hornblower \& Weeks, and before the end of I goo Mr. Wing was really the manager of the Massachusetts National, though he was not formally made president until 1903. When the Massachusetts National merged with the First National, later in 1903, he was made president of the First National Bank. He continued to hold this position until I 926, when he was elected chairman of the board. In addition he was a director and member of the executive committee of other corporations, including the Pacific Mills, United Fruit Company, United Shoe Machinery, New England Power Association, and the United States Smelting, Refining and Mining Company. He had been a member of the Business Historical Society since 1927 .

Those who knew him will heartily concur in the following statement from an editorial which the Boston Evening Transcript published on Mr. Wing: "By his constructive powers he led this institu- 